\title{
Development of Ultraviolet Spectrophotometric Method for Analysis of Lornoxicam in Solid Dosage Forms
}

\author{
Sunit Kumar Sahoo ${ }^{1 *}$, Ranjit Kumar Giri ${ }^{1}$, Sachin V Patil ${ }^{2}$, Amulya Ratna \\ Behera $^{1}$ and Ranjit Mohapatra ${ }^{1}$ \\ ${ }^{1}$ University Department of Pharmaceutical Sciences, Utkal University, Bhubaneswar, Orissa, ${ }^{2}$ Department of \\ Pharmaceutics, Shree Santkrupa College of Pharmacy, Ghogaon, Tal. Karad, Dist. Satara, Maharashtra, India
}

\begin{abstract}
Purpose: An ultraviolet spectrophotometric system was developed and validated for the quantitative determination of lornoxicam in solid dosage forms.

Methods: Lornoxicam was dissolved in $0.01 \mathrm{M} \mathrm{NaOH}$ and analysed using ultraviolet (UV) spectrophotometry. Various analytical parameters such as linearity, precision, accuracy, limit of detection (LOD) and limit of quantification (LOQ) were determined according to International Conference on Harmonization (ICH) guidelines.

Results: Absorbance maximum in $0.01 \mathrm{M} \mathrm{NaOH}$ was $377 \mathrm{~nm}$. Beer's law was obeyed over the concentration range of $2-20 \mu \mathrm{g} / \mathrm{ml}$ with a correlation coefficient $\left(r^{2}\right)$ value of 0.999 . Percent range of error was 0.344 and 0.261 at 0.05 and. 0.01 confidence limits, respectively. Intra- and inter-day precision $(\% R S D)$ at different concentration levels were $<2 \%$, indicating that the proposed derivative spectrophotometric method is highly reproducible during one run and between different runs; LOD and $L O Q$ were 0.105 and $0.318 \mu \mathrm{g} / \mathrm{ml}$, respectively signifying that it can be adopted for routine quality testing. Mean recovery was $100.82 \%$ for tablets. Low values of $\% R S D$ indicate the reliability of the proposed method

Conclusion: The proposed method is highly sensitive, precise, accurate, cost-effective, reliable and rapid for the estimation of lornoxicam in solid dosage forms.
\end{abstract}

Keywords: Lornoxicam, UV Spectrophotometry, Quantitative determination, Solid dosage forms. 


\section{INTRODUCTION}

Lornoxicam (6-chloro-4-hydroxy-2-methyl-N2-pyridyl-2H-thieno-[2,3-e]-1,2-thiazine-3carboxamide-1,1-dioxide) a non-steroidal anti-inflammatory drug (NSAID) with potent analgesic and anti-inflammatory activity. It belongs to the class of oxicams and is approximately ten times more potent than oxicams such as piroxicam and tenoxicam [1]. It is used for the treatment of rheumatoid arthritis and other rheumatic diseases and is available in the market as tablet and injection.

A literature survey showed that the analysis of lornoxicam in pharmaceutical preparations is usually by high performance liquid chromatography (HPLC), voltammetry as well as zero- and first-order derivative UV spectrophotometric methods [2],. However, to the best of our knowledge, no method has been established and validated by linear regression equation method which is a promising straightforward method that has gained extensive recognition.

The objective of the present study was to develop a simple, precise and reliable spectrophotometric method, using $0.01 \mathrm{M}$ $\mathrm{NaOH}$ as solvent, as a rapid, direct and costeffective alternative to the determination of lornoxicam in pharmaceutical formulations.

\section{EXPERIMENTAL}

\section{Materials}

A commercial brand of lornoxicam tablet, Zion $^{\circledR}$, (,8 mg lornoxicam, Unichem, India) was obtained from a local pharmacy. Lornoxicam powder (purity, $99.9 \%$ ), received gratis from Hetero Drugs, Hyderabad, India, was used as such without further purification. All other chemicals used were of analytical grade. All the solutions for analysis were freshly prepared and analyzed. Spectrophotometric analysis was performed with Systronic 2101 and Elico SL 159 UV-Vis spectrophotometer. Addir Dutt electronic balance (AD-50B, Kolkata, India) was used for the assessment of tablet weight variation.

\section{Preparation of working standard solutions}

A working standard solution of lornoxicam was prepared by dissolving $50 \mathrm{mg}$ of the standard (pure) lornoxicam in an appropriate volume of $0.01 \mathrm{M} \mathrm{NaOH}$ to obtain a solution of $100 \mu \mathrm{g} / \mathrm{ml}$ concentration. Aliquots $(1-10 \mathrm{ml})$ of the working standard solution were transferred into a series of $50 \mathrm{ml}$ volumetric flasks to obtain final drug concentrations of 2 - $20 \mu \mathrm{g} / \mathrm{ml}$.

\section{Analysis of the drug and validation of the proposed method}

Twenty tablets of lornoxicam were crushed in a mortar and pestle to a fine powder and an amount equivalent to $8 \mathrm{mg}$ (accurately weighed) was extracted at room temperature in a shaker with $100 \mathrm{ml} 0.01 \mathrm{M} \mathrm{NaOH}$ for 45 min. The mixture was filtered through Whatman filter paper no. 1 . and suitably diluted with $0.01 \mathrm{M} \mathrm{NaOH}$ to obtain a concentration of $10 \mu \mathrm{g} / \mathrm{ml}$ of lornoxicam [3]. The absorbance of these solutions was determined at $377 \mathrm{~nm}$ against a reagent blank $(0.01 \mathrm{M} \mathrm{NaOH}$ solution). The repeatability of the method was established by carrying out analysis $(n=8)$ of the analyte $(10 \mu \mathrm{g} / \mathrm{ml})$ using the proposed method [4].

\section{Recovery studies}

The accuracy of the developed assay method was evaluated by evaluating the recovery of lornoxicam by standard addition method at concentrations of 80,100 and $120 \%$ of the target level in tablets [5]. The percent analytical recovery was calculated by comparing the concentration obtained from spiked samples with actual added concentration and the values are listed in Table 1.

The precision of the method was demonstrated by inter-day and intra-day variation studies using three different concen- 
Sahoo et al

Table 1: Recovery data for lornoxicam tablets by proposed method

\begin{tabular}{|c|c|c|c|c|}
\hline $\begin{array}{c}\text { Sample } \\
\text { ID }\end{array}$ & $\begin{array}{l}\text { Concentration of } \\
\text { pure drug taken } \\
(\mu \mathrm{g} / \mathrm{ml})\end{array}$ & $\begin{array}{c}\text { Concentration of tablet } \\
\text { formulation } \\
(\mu \mathrm{g} / \mathrm{ml})\end{array}$ & $\begin{array}{c}\text { \% Recovery of pure } \\
\text { drug } \\
(n=3)\end{array}$ & $\%$ RSD \\
\hline $\mathrm{C}: 80 \%$ & 8 & 10 & $99.91 \pm 0.830$ & 0.831 \\
\hline C : $100 \%$ & 10 & 10 & $100.38 \pm 0.880$ & 0.877 \\
\hline C : $120 \%$ & 12 & 10 & $102.18 \pm 0.322$ & 0.316 \\
\hline
\end{tabular}

Note: $R S D$ = relative standard deviation

Table 2: Precision data $(n=3)$

\begin{tabular}{lcccc}
\hline $\begin{array}{l}\text { Amount taken } \\
(\mu \mathrm{g} / \mathrm{ml})\end{array}$ & $\begin{array}{c}\text { Inter-day } \\
\text { Content }(\mu \mathrm{g} / \mathbf{m l})\end{array}$ & $\begin{array}{c}\text { Intra-day } \\
\text { RSD }\end{array}$ & $\begin{array}{c}\text { Content }(\boldsymbol{\mu g} / \mathbf{m I}) \\
\% \boldsymbol{R S D}\end{array}$ \\
\hline 8 & $7.940 \pm 0.054$ & 0.690 & $7.98 \pm 0.013$ & 0.168 \\
10 & $9.940 \pm 0.077$ & 0.775 & $9.98 \pm 0.014$ & 0.134 \\
12 & $11.960 \pm 0.044$ & 0.372 & $11.97 \pm 0.026$ & 0.225 \\
\hline
\end{tabular}

Note: $R S D=$ relative standard deviation

trations of drug (in addition to calibration standards) covering the entire linearity range [6]. In intra-day studies, the drug was analyzed on the same day while inter-day precision was determined by analyzing the drug for three consecutive days. The results are presented as standard deviation and \% relative standard deviation (R.S.D) in Table 2.

\section{Reliability}

The reliability of the proposed method was determined at $12 \mu \mathrm{g} / \mathrm{ml}$ by using different instruments that is by Systronic 2101 and Elico SL 159 UV-Vis spectrophotometer under similar setting [7].

Limits of detection (LOD) and quantification (LOQ)

LOD and LOQ were calculated as $3.3 \mathrm{\sigma} / \mathrm{S}$ and $10 \sigma / S$, respectively, where $\sigma$ is the standard deviation of the standard concentration and $S$ is the slope of the standard curve. The limit of detection (LOD) is the lowest concentration of an analyte that an analytical process can reliably differentiate from background levels. The limit of quantification (LOQ) is the lowest concentration of the standard curve that can be measured with acceptable accuracy, precision and variability [8].

\section{Statistical analysis}

The data obtained were expressed as mean \pm standard deviation (SD), and statistical analysis of the data was performed using one-way ANOVA (Graph Pad Prism software, version 5). Differences between formulations were considered to be significant at $p \leq 0.05$.

\section{RESULTS}

The optical characteristics were as follows: Beer's law limit, 2 to $20 \mu \mathrm{g} / \mathrm{ml}$; absorbance maximum, $377 \mathrm{~nm}$; molar absorptivity, $465.065 \mathrm{~L} \mathrm{M}^{-1} \mathrm{~cm}^{-1}$; Sandell's sensitivity, 0.023 $\mu \mathrm{g} \mathrm{cm} / 0.001$ absorbance unit; correlation coefficient $\left(r^{2}\right)$, > 0.999; regression equation, $y=0.043 X+0.016$; slope, 0.043 ; intercept, 0.016 ; \% RSD, 0.834; and \% range of error, 0.344 and 0.261 at 0.05 and 0.01 confidence limits, respectively. Molar absorptivity and Sandell's sensitivity data show that the method is perceptive. The assay value for the commercially marketed tablet was $99.91 \%$ with a \% R.S.D. 0.831.

Mean recovery was $100.82 \%$ for the tablets by the proposed method while LOD and LOQ were 0.105 and $0.318 \mu \mathrm{g} / \mathrm{ml}$, respectively. The intra- and inter-day precision (\% RSD) at different concentration levels were $<2 \%$ (Table 2), indicating that the proposed derivative spectrophotometric method is 
Table 3: Results of reliability studies

\begin{tabular}{cccc}
\hline UV spectrophotometer & $\begin{array}{c}\text { Amount taken } \\
(\mu \mathrm{g} / \mathrm{ml})\end{array}$ & $\begin{array}{c}\text { Amount found } \\
(\mu \mathrm{g} / \mathrm{ml})\end{array}$ & $\%$ RSD \\
\hline Systronics-2101 & 12 & $11.98 \pm 0.01$ & 0.083 \\
Elico SL-159 & 12 & $11.95 \pm 0.02$ & 0.174 \\
\hline
\end{tabular}

Note: $R S D$ = relative standard deviation

highly reproducible during one run and between different runs [9]. Low values of \% RSD for reliability studies (Table 3 ) at $p \leq$ 0.05 indicate that there was no statistically significant difference between the two different UV spectrophotometric instruments used in a similar setting.

\section{DISCUSSION}

The present study is an attempt to develop a simple, accurate and sensitive UV spectrophotometric method for the determination of lornoxicam in solid dosage forms, specifically tablets. The linearity of lornoxicam solution in the concentration range 2 to $20 \mu \mathrm{g} / \mathrm{ml}$ was satisfactory with absorbance maximum at $377 \mathrm{~nm}$. The low values of standard error established the precision of the proposed method. The low values of LOQ and LOD of the proposed method signify that it can be adopted for routine quality testing and dissolution studies. Sample recovery for tablets was in good agreement with its label claim. The withinday and between-day precision (\% RSD ) were satisfactory and established the repeatability and reproducibility of the proposed method.

\section{CONCLUSION}

The proposed UV method for the analysis of lornoxicam is simple, fast and reliable, providing satisfactory accuracy and precision. Moreover, the short duration of analysis of lornoxicam make the developed method suitable for the routine quantitative analysis of lornoxicam in solid dosage formulations.

\section{ACKNOWLEDGEMENT}

The authors are grateful to Hetero Drugs, Hyderabad, India, for providing pure lornoxicam free of charge.

\section{REFERENCES}

1. Balfour JA, Fitton A, Barradell LB. Lornoxicam. A review of its pharmacology and therapeutic potential in the management of painful and inflammatory conditions. Drugs 1996; 51(4): 639-657.

2. Nemutlu E, Demircan S, Kir S. Determination of lornoxicam in pharmaceutical preparations by zero and first order derivative UV spectrophotometric methods. Pharmazie 2005; 60: 421-425

3. Borgmann SH, Parcianello LM, Arend MZ, Cardoso SG. Direct spectrophotometric determination of diacerhein in tablets. Pharmazie 2007; 62: 483-485.

4. Gandhi SV, Barhate NS, Patel BR, Panchal DD, Bothara KG. A validated densitometric method for analysis of aceclofenac and paracetamol as the bulk drugs and in combined tablet dosage forms. Acta Chromatogr 2008; 20: 175-182.

5. Saha RN, Sajeev $C$, Jadhav $P R$, Patil $S P$, Srinivasan N. Determination of celecoxib in pharmaceutical formulations using uv spectrophotometry and liquid chromatography. $J$ Pharm Biomed Anal 2002; 28: 741-751.

6. Basavaiah K, Anil KR. Simple Spectrophotometric Methods for the Determination of Zidovudine in Pharmaceuticals Using Chloramine-T Methylene Blue and Rhodamine- $B$ as Reagents. E Journal of Chemistry 2006; 3: 173-181.

7. Saharty E, Refaat YS, Khateeb ME. StabilityIndicating Spectrophotometric and Densitometric Methods for Determination of Aceclofenac. Drug Develop Ind Pharm 2002; 28: 571-582.

8. Argekar AP, Sawant JG. Determination of cisapride in pharmaceutical dosage forms by reversedphase liquid chromatography. J Pharm Biomed Anal 1999; 21: 221-226.

9. Sarkar $M$, Khandavilli $S$, Panchagnula $R$. Development and validation of rp-hplc and

Trop J Pharm Res, April 2012;11 (2):272 
Sahoo et al

ultraviolet spectrophotometric methods of analysis for the quantitative estimation of

antiretroviral drugs in pharmaceutical dosage forms. J Chromatogr 2006; 830: 349-354.

Trop J Pharm Res, April 2012;11 (2):273 